\title{
Employees' Work Motivation during COVID-19 Outbreaks: A Comparative Study of Missionary and Govt. Schools
} Chandan Kumar Sinha ${ }^{1 *}$, Dr. Anis Ahmad ${ }^{2}$

\author{
${ }^{1} \mathrm{PhD}$. University Department of Psychology, L. N. Mithila University, Darbhanga - 846004, India \\ ${ }^{2}$ Professor, University Department of Psychology, L. N. Mithila University, Darbhanga - 846 004, India
}

DOI: $10.36348 /$ sjhss.2020.v05i10.006

| Received: 27.09.2020| Accepted: 04.10.2020| Published: 08.10.2020

*Corresponding author: Chandan Kumar Sinha

\section{Abstract}

Recent developments and researches have proved that old or traditional management models as typical hierarchical organizational structure, autocracy, tight control, close supervision, etc are not effective and would not fit the current organizational conditions especially to school organizations. Many Indian government schools find themselves unable to compete in retaining talent globally when compared to missionary school employees working in India due to their high level of work motivation. Therefore, the present study was aimed at studying the employees' work motivation during COVID - 19 pandemic among teaching and non - teaching employees working in Government and Missionary Schools with particular reference to North Bihar. To measure the differences between Government and Missionaries Schools employees in terms of their levels of work motivation during COVID-19 outbreaks, total sample consisted of one hundred sixty $(\mathrm{N}=180)$ which were randomly selected from different Government and Missionaries Schools located at North Bihar, viz., Begusarai, Darbhanga, Madhubani and Samastipur. These are well - known towns of North Bihar. The break up of the total sample comprises Government school teachers $(n=45)$ and Govt. school Non - teacher $(n=45)$ and similarly Missionary School teachers $(\mathrm{n}=45)$ and Missionary School Non - teacher $(\mathrm{n}=45)$. Total respondents' age were ranged between 30 to 58 years of age. Having collected the information on the problem through questionnaire schedule, the data were tabulated as per norms of the schedule for giving statistical treatment. Obtained results indicated significant differences in terms of teaching employees' work motivation between the group of Government School and Missionary school. It is important to mention here that the levels of work motivation among Government school teaching employees have been found little high as compared to missionary school teaching employees but had not shown significant difference during COVID-19 outbreaks. Finally discrepancy of obtained results has been discussed in detail by highlighting the probable reasons.

Keywords: Work Motivation, Employee, Govt. School, Missionary School, North Bihar, India.

Copyright (C) 2020 The Author(s): This is an open-access article distributed under the terms of the Creative Commons Attribution license which permits unrestricted use, distribution, and reproduction in any medium for non-commercial use (Non - Commercial, or CC-BY-NC) provided the original author and source are credited.

\section{INTRODUCTION}

In the work environment, motivation plays a pivotal role. During the COVID - 19 outbreaks employees who are employed in different positions not only in educational institutions but in any organization has been observed low work motivation. Thus, the present enquiry was planned to see the levels of work motivation during COVID-19 outbreaks with special reference to missionary and government school employees.

In fact, work motivation is a set of energetic forces that originate both within as well beyond an individual's being, to initiate work related behavior, and to determine its form, direction, intensity, and duration
Pinder [1]. It is generally believed that motivation is a person's internal disposition to be concerned with and approach positive incentives and avoids negative incentives as further advocated by Deckers [2] that an incentive is the anticipated reward or aversive event available in the environment. While motivation can often be used as a tool to help predict behavior, it varies greatly among individuals and must often be combined with ability and environmental factors to actually influence behavior and performance. Inceoglu et al., [3] who examined age related difference in work motivation and suggested that shift in people's motives rather than a general decline in motivation with age. That is, it seemed that older employees were less motivated by extrinsically related features of a job, but 
more by intrinsically rewarding job features although, work motivation is strongly influenced by certain cultural characteristics. Currently work motivation research has explored motivation that may not be consciously driven. This method goal setting is referred to as goal priming.

It is important to mention that for organizations to understand and to structure the work environment to encourage productive behaviors and discourage those that are unproductive given work motivation's role in influencing workplace behavior and performance $[4,5]$, although, motivational systems are at the center of behavioral organization. It is because of the fact that behavior is a discrepancy - reduction process, whereby individuals act to minimize the discrepancy between their present condition and a desired goal. If we look at this from the standpoint of how leaders can motivate their followers to enhance their performance, participation in any organization involves exercising choice; a person chooses among alternatives, responding to the motivation to perform or ignore what is offered.

When employees are incentivized at work, they reach higher levels of success and provide the organization with greater value through their performance. In order to increase the productivity of the employees in any organization, it's important to focus on motivating and inspiring them. When our employees are motivated, they will aim to complete each task more efficiently in a timely manner and will concentrate on the quality of their work.

American psychologist Frederick Herzberg coined the Motivation-Hygiene Theory in 1959, which said that employees need more than just their salary in order to be motivated at work. Employees have two kinds of motivation: internal \& external.

In order to increase the efficiency of employees, they need to understand and respond to both of these kinds of motivation.

Internal motivations include things like emotions and thoughts, such as being bored with doing the same task for several years compared to being excited and challenged by new and different tasks. External motivations include aspects such as salary and work environment, like the cubicle or factory floor.

According to Herzberg, if a business wants to have motivated employees, it needs to address both the external and internal factors to ensure that its employees are satisfied. While providing employees with a raise or a bonus may seem like a good incentive, it's not enough to always compel an employee to be motivated. Instead, businesses need to also consider aspects such as emotions and thoughts.
Apart from the above context, it is to mention that work motivation studies aim to discover what it is that triggers performance. Klonoski, R [6] opines that motivation is the term used to describe those processes, both instinctive and rational by which people seek to satisfy their basic drives, perceived needs and personal goals which trigger performance.

Motivation is a human psychological characteristic that contributes to a person's degree of commitment. Motivation is essential to organizational effectiveness and is a predictor for performance of employees [7].

Shafique and Hussain [8] observed that employees' aspirations and target do not always match with what their employer can provide. It has been suggested that proper motivation can significantly influence the attitude of workers towards their jobs and hence affect the performance of such employees on the job.

There is need to understand why people choose to perform satisfactorily; why some people appear to be committed to their jobs and others are often absent. People are usually willing to work harder when they expect to benefit by doing so. In other words, people exert effort when the effort helps them meet some personal needs. Commitment is a product of motivation [9].

Moreover, there are a number of barriers to job motivation in the modern workplace. For many employees, motivation is directly tied to their manager. If the supervisor is micromanaging the employees' every move, it can feel as though they are not trusted, which is demoralizing. Poor job performance reviews and appraisals can also be difficult. While critical feedback is necessary for success, managers can phrase feedback in a positive way to help energize employees.

Lack of rewards such as salary, bonuses and benefits are another barrier to work motivation. In order to increase job productivity and efficiency, organization need to properly reward employees with market-rate salaries, bonuses tied to performance and competitive benefits packages.

The performance of the organization can also be a vital motivational factor. If the organization is undergoing financial trouble and is frequently lying off employees, then the workers may not be energized enough to put forward their best at work, assuming that they will also be laid off. Similarly, if the organization isn't performing well as a whole, the employees may feel that their team members aren't putting in enough effort, and they may follow suit [10]. Moreover, various studies has been conducted on the work motivation in relation to different psycho - social dimensions in 
general and on the dimensions of organizational behavior in particular by Kamery [11]; Lee - Ross [12]; Mishra [13]; Patterson [14]; Pestonjee and Basu [15]; Rollag [16]; Saiyadain [17] and Smith [18] but it is important to mention here that none of the studies has yet been investigated with reference to Govt. and Missionary School employees as the topic chosen by the present investigators. Thus, the present study is of utmost value.

\section{Aims and Objectives of the Present Study}

Having observed the fact pertaining to work motivation during COVID-19 outbreaks, it has been decided to work on Employees' Work Motivation during COVID- 19 Outbreaks with particular reference to Missionary and Govt. Schools located in located in North Bihar. Basically, work motivation is an important aspect of organizational behavior and at each moment it requires attention even during COVID - 19 pandemic too. It is important to point out here that motivation doesn't stop at the end of the workday in any situation. When employees go home, many of them take their work home with them because they feel the need to do so in order to show the organization that they are committed. Instead of making this an expectation, encourage employees to take time to be with their friends and family instead.

Bringing fun elements into the office space can also encourage work-life balance. For example, many organizations have items like a table tennis or video games, TV in the common room to encourage employees to take a few minutes off to recharge and enjoy each other. This shows our employees that we value them and want them to have fun at work by taking precautions in the times COVID-19 pandemic, which is a definite motivating factor.

Having scanned the review of literature on work motivation among employees, it has been observed that various studies are available but none of studies found in Indian context with reference to COVID - outbreaks. Hence, it has been decided to work on Employees' Work Motivation during COVID19 Outbreaks with particular reference to Missionary and Government Schools located at different areas of North Bihar. Thus, the present study is of immense value and will fill the void of knowledge in the area of organizational behavior.

\section{Hypotheses}

On the basis of broad aims and objectives of the present study, the following hypotheses have been formulated:

- There will be no significant difference between government school teachers and missionary school teachers in terms of their degree of work motivation in the times of COVID-19 outbreaks.
- $\quad$ There will be no significant difference between teaching and non - teaching employees working in government school in terms of their degree of work motivation in the times of COVID-19 outbreaks.

- There will be no significant difference between teaching and non - teaching employees working in missionary schools in terms of their degree of work motivation in the times of COVID - 19 outbreaks.

- Total employees (teaching \& non - teaching) of government school will not differ on work motivation from the total employees (teaching $\&$ non - teaching) working in missionary schools in the times of COVID - 19 pandemic.

\section{RESEARCH METHODOLOGY Sample}

During the period of COVID - 19 pandemic, data collection is not an easy job but I had tried to contact the employees of government school and missionary school located in and around Mithila region to get information online and most of the respondents were agreed to participate in the present inquiry. The towns of Mithila region given priorities for data collection were Begusarai, Barauni, Darbhanga, Madhubani and Samastipur. For the present piece of research work, due to the hardship, total sample consisted of one hundred sixty $(\mathrm{N}=180)$ which were randomly selected by contacting on Mobile, WhatsApp, facebook and Google mail, etc from different Government and Missionary School employees. Moreover, all subjects were personally contacted by requesting them for gathering the information also. Total sample comprises Government School teachers $(n=45)$ and Govt. school Non -teacher $(n=45)$ and similarly Missionary School teachers $(n=45)$ and Missionary School Non - teacher $(n=45)$. Total respondents' age were ranged between 30 to 58 years of age.

\section{Tools and Materials Used}

For the present piece of research work, the following tools were used for data collection:

1. To measure the degree of "Employees' Work Motivation" - a scale developed by Agrawal [19] was used. In this scale, there are 26 items which were rated on Likert 5 - point scale ranging from 'very satisfied with my job'; 'fairly satisfied'; 'neither satisfied nor dissatisfied', 'somewhat dissatisfied' and 'very dissatisfied from my job'. The reliability of the scale is 0.994 and validity 0.59 reported by the author which confirms the efficacy of the scale. In this scale higher score indicates high degree of work motivation.

2. Biographical Information blank (BIB): For taping information regarding the respondents' biographies, a 'Biographical Information Blank' (BIB) was also prepared that included 
age, marital status, salary (basic and gross), qualification, designation, department, total experience (in years), present experience (in years) and number of dependents and the respondents were requested to furnish these information.

\section{Procedure}

The above two test materials viz., Employees' Work Motivation scale and, biographical information blank were in printed form and were administered individually online and were provided to all the employees (teaching and non - teaching) working in different government and missionary schools of Mithila region. All the employees were assured by taking them in to confidence that provided information will be kept strictly confidential and will be used for research purposes only. Having collected the responses to the items of the scales, they were scored according to the procedure and the individual scores were obtained for giving statistical treatment and finally presented in the tables.

\section{RESULTS AND DISCUSSION}

In quest of obtaining the results, descriptive analysis was done by computing mean, $\mathrm{SD}$, and t-test to see if there was any significant difference in obtained scores pertaining to employees' work motivation between Government school teachers and Missionary school teachers. From the table-1, it is apparently clear that in the present sample there is a no significant difference in the mean values of work motivation during COVID-19 between the group of teachers working in Missionary school and Govt. School as t value i.e. 1.74 is found to be insignificant statistically. Thus, the hypothesis formulated that there will be no significant difference between Government school teachers and Missionary School teachers in the degree of their work motivation stands accepted. The result seems to be logical that Government and Missionary school teachers do not differ in their work motivation so far as their psycho - social make up of their organizational personality is concerned. It is important to point out here that one of the possible reasons for the present study is Missionary schools and its employees are highly committed than those teaching and non teaching employees who are employed in the Government schools but during the COVID-19 has been found statically insignificant especially from where the present study was carried out.

Table-1: Showing Significant Difference between Government and Missionary School Teachers in terms of their degree of Work Motivation during COVID - 19

\begin{tabular}{|l|l|l|l|l|l|}
\hline GROUPS & N & Mean & S.D & t & Significance Level \\
\hline Missionary School Teachers & 45 & 96.7 & 9.06 & & \\
\cline { 1 - 4 } Government School Teachers & 45 & 100.2 & 10.35 & 1.74 & Insignificant \\
\hline
\end{tabular}

Table-2: Showing Comparative Levels of Perceived Degree on Work Motivation during COVID - 19 among Teachers Working in Govt. and Missionary Schools

\begin{tabular}{|l|l|l|l|l|}
\hline \multirow{2}{*}{ Levels } & GROUP & Percentage \\
\cline { 2 - 5 } & Missionary Schools Teaching Employees & Government Schools Teaching Employees \\
\cline { 2 - 5 } & $\mathrm{n}=45$ & Percentage & $\mathbf{n}=45$ & $\mathbf{4 0 . 0 0 \%}$ \\
\hline High & 15 & $33.33 \%$ & 15 & $33.33 \%$ \\
\hline Moderate & 14 & $31.11 \%$ & 12 & $26.67 \%$ \\
\hline Low & 16 & $35.56 \%$ & $\begin{array}{c}\text { Mean value }=96.7 \\
\text { Mean value }=100.2\end{array}$
\end{tabular}

Table-2 is the extension of Table-1 by which we can observe that 33.33 percent of missionary school teachers have shown higher acceptability of work motivation and on the other hand 40.00 percent of government teaching employees had shown higher degree of perceived degree on work motivation which higher than the missionary school teachers in the times of COVID-19. 33.33 percent of teachers working in government schools have reported moderate level of perceived reactions on work motivation in comparison to the teachers working in missionary schools i.e. 31.11 percent. Though, 35.56 percent of teaching employees of missionary school had shown low but positive reactions on perceived work motivation as compared to the teachers working in government schools i.e. 26.67 percent. The presented results can also be observed by the following figure. 


\section{Chart Showing Comparative Levels of Perceived \\ Reactions on Work Motivation during COVID - 19 among \\ Teachers Working in Govt. and Missionary Schools}

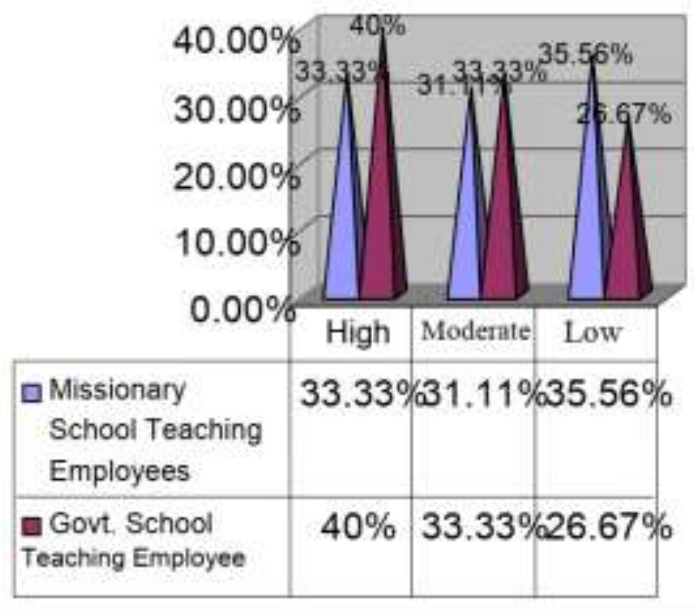

$\square$ Missionary School Teaching Employees

$\square$ Govt. School Teaching Employees

Table-3 depicts the picture pertaining to the significant difference between teaching and non teaching employees working in government schools in terms of their degree of work motivation. From the Table-3 it could be observed that government teaching employee scored higher on work motivation scale (Mean - 100.2 with an SD 10.35) as compared to non - teaching employees (Mean - 86.34 with an SD 8.82) working in the same institutions. Hence, the formulated hypothesis i.e. there will be no significant difference between teaching and non - teaching employees working in government school in terms of their degree of work motivation in the time of COVID - 19 outbreaks, stands accepted as the $\mathrm{t}-7.19$ value has been found highly significant statistically at .01 level of confidence. The result seems to be logical in the sense that during the COVID-19 outbreaks most of the teachers of government schools were engaged in teaching - learning processes online as per the directions of the Government of India and on the other hand non - teaching employees of the schools were engaged in doing daily life routine work only by maintaining social distancing during work. Hence, it is observed that teaching employees' work performance to work from home during the COVID-19 outbreaks is highly appreciated by every one. Thus, they score higher degree on work motivation as compared to non - teaching employees in the same institution.

Table-3: Showing Significant Difference between Teaching and Non - Teaching Employees Working in Government Schools in terms of their degree of Work Motivation

\begin{tabular}{|l|l|l|l|l|l|}
\hline GROUPS & N & Mean & S.D & t & Significance Level \\
\hline Government School Teaching Employees & 45 & 100.2 & $\mathbf{1 0 . 3 5}$ & \multirow{2}{*}{7.19} & $\mathbf{0 . 0 1}$ \\
\cline { 1 - 4 } Government School Non - Teaching Employees & 45 & $\mathbf{8 6 . 3 4}$ & $\mathbf{8 . 8 2}$ & & \\
\hline
\end{tabular}

Table-4: Showing Comparative Levels of Perceived Degree on Work Motivation during COVID - 19 among Teaching and Non - Teaching Employees Working in Government Schools

\begin{tabular}{|c|c|c|c|c|}
\hline \multirow[t]{3}{*}{ Levels } & \multicolumn{4}{|c|}{ GROUP } \\
\hline & \multicolumn{2}{|c|}{ Government Schools Teaching Employees } & \multicolumn{2}{|c|}{ Government Schools Non -Teaching Employees } \\
\hline & $n=45$ & Percentage & $n=45$ & Percentage \\
\hline High & 18 & $40.00 \%$ & 14 & $31.11 \%$ \\
\hline Moderate & 15 & $33.33 \%$ & 16 & $35.56 \%$ \\
\hline Low & 12 & $26.67 \%$ & 15 & $33.33 \%$ \\
\hline
\end{tabular}

Mean value $=\mathbf{1 0 0 . 2}$

Mean value $=86.34$

Table -4 is also the extension of Table -3 which highlight the comparative levels of perceived degree on work motivation among teaching and non - teaching employees working in government schools. From the Table-4, it can be observed that 40 percent of teaching employees working in government school had shown higher degree of perceived reactions on work motivation as compared to non - teaching employees i.e. 31.11 percent in the same institution, whereas, 35.56 percent of non - teaching employees have reported to 
moderate level of perceived reactions on to work motivation in comparison to teaching employees in the same institution. Similarly, 33.33 percent of non teaching employees working in government schools had shown low but positive reactions to work motivation as compared to teaching employees i.e. 26.67 percent.
Overall, it can be observed that teaching employees of the government schools performed better during COVID-19 outbreaks by taking self precautions and as directed by Government of India. The results discussed above can also be observed by following figure;

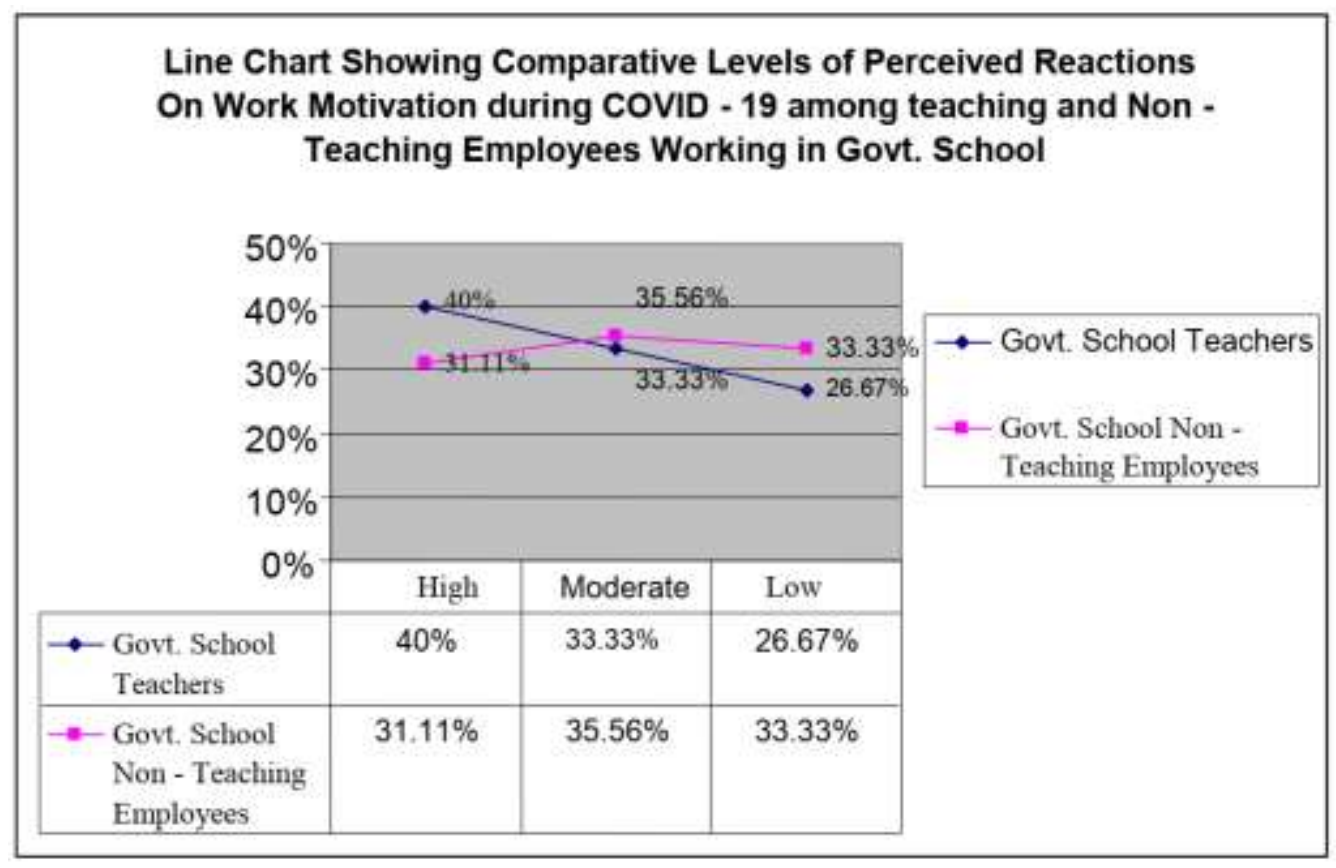

Table-5: Showing Significant Difference between Teaching and Non - Teaching Employees Working in Missionary Schools in terms of their degree of Work Motivation

\begin{tabular}{|l|l|l|l|l|l|}
\hline GROUPS & N & Mean & S.D & t & Significance Level \\
\hline Missionary School Teaching Employees & 45 & $\mathbf{9 6 . 6}$ & $\mathbf{9 . 0 6}$ & $\mathbf{4 . 3 2}$ & $\mathbf{0 . 0 1}$ \\
\hline Missionary School Non -Teaching Employees & $\mathbf{4 5}$ & $\mathbf{8 8 . 3 4}$ & $\mathbf{8 . 8 2}$ & & \\
\hline
\end{tabular}

Similarly, Table- 5 of the results depicts the clear cut picture regarding significant difference between teaching and non - teaching employees working in missionary schools. From the Table-5 it could be observed that missionary school teachers had scored higher on work motivation questionnaire (Mean - 96.6 with an SD 9.06) during the COVID-19 out breaks in comparison to non - teaching employees (Mean - 88.34 with an SD 8.82). Hence, the formulated hypothesis i.e. there will be no significant difference between teaching and non - teaching employees working in missionary schools in terms of their degree of work motivation in the time of COVID -19 outbreaks, stands rejected as the $\mathrm{t}-4.32$ has been found highly significant statistically at .01 level of confidence. The presented results also seem to be logical as discussed above (Tables $3 \& 4$ ). There may be some differences pertaining to their salary and other perks and benefits especially during the period of COVID-19 outbreaks in comparison to Government Schools but it is observed, more or less is the same conditions during COVID - pandemic.

Table-6: Showing Comparative Levels of Perceived Degree on Work Motivation during COVID - 19 among Teaching and Non - Teaching Employees Working in Missionary Schools

\begin{tabular}{|c|c|c|c|c|}
\hline \multirow[t]{3}{*}{ Levels } & \multicolumn{4}{|c|}{ GROUP } \\
\hline & \multicolumn{2}{|c|}{ Missionary Schools Teaching Employees } & \multicolumn{2}{|c|}{ Missionary Schools Non - Teaching Employees } \\
\hline & $\mathrm{n}=\mathbf{4 5}$ & Percentage & $n=45$ & Percentage \\
\hline High & 15 & $33.33 \%$ & 9 & $20.00 \%$ \\
\hline Moderate & 14 & $31.11 \%$ & 16 & $35.56 \%$ \\
\hline Low & 16 & $35.56 \%$ & 20 & $44.44 \%$ \\
\hline
\end{tabular}

Table-6 highlight the comparative levels of perceived degree on work motivation during COVID19 among teaching and non - teaching employees working in missionary schools. It is clear from the Table-6 that 33.33 percent teaching employees of missionary schools have shown higher degree of work 
motivation in comparison to non - teaching employees working in the same institutions i.e. 20 percent only, whereas, 35.56 percent of non - teaching employees had reported to have moderate level of work motivation during COVID-19 pandemic. Moreover, 44.44 percent of non - teaching employees had shown low but favorable reactions on work motivation as compared to missionary schools teaching employees. Overall working culture in missionary school has been found satisfactory but it seems that the variation is due to lockdown of COVID-19 pandemic. The presented and discussed result can also be understood by the following figure:

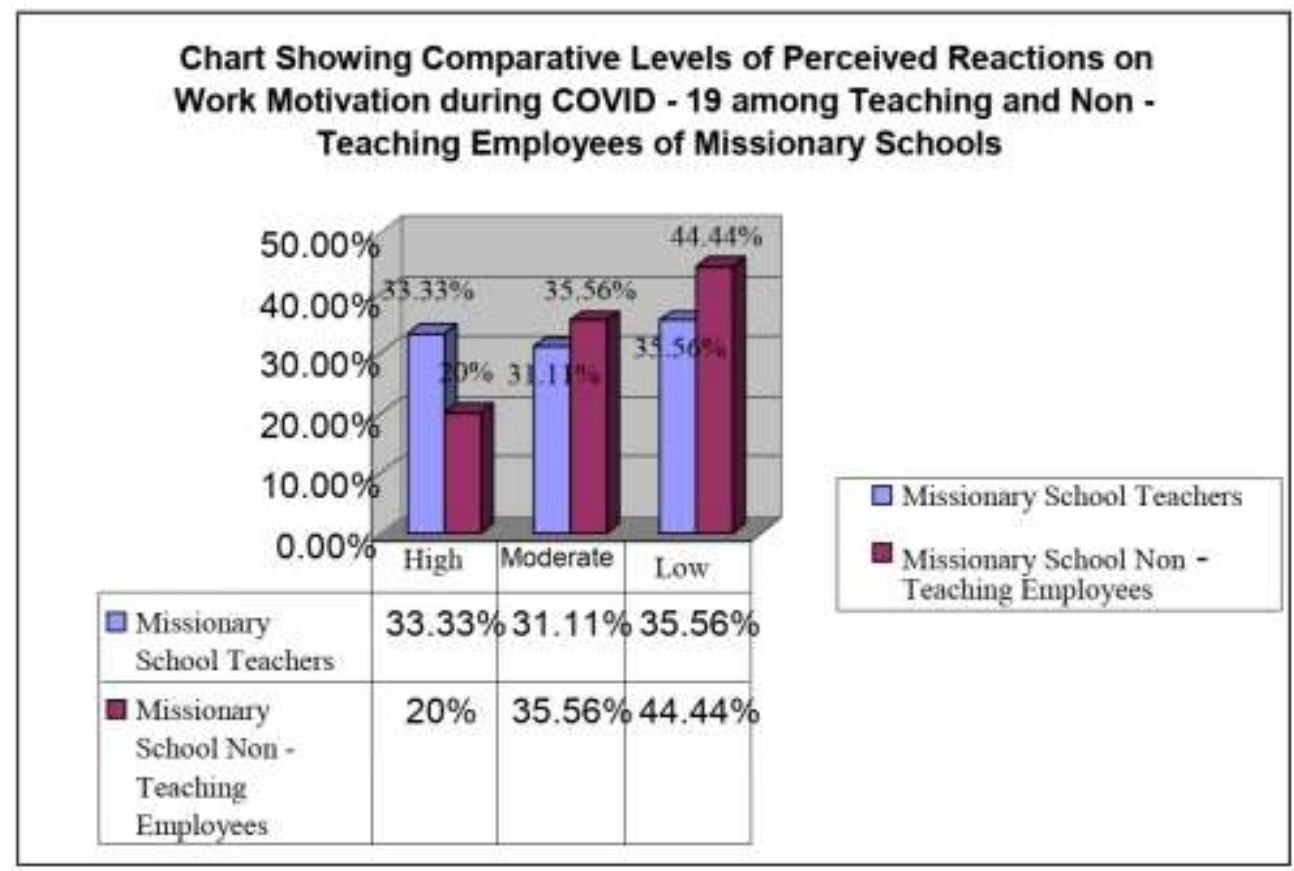

Table-7: Showing Significant Difference between Employees Working in Missionary \& Govt. Schools in terms of their degree of Work Motivation during COVID - 19 (Total Sample)

\begin{tabular}{|l|l|l|l|l|l|}
\hline GROUPS & N & Mean & S.D & t & Significance Level \\
\hline Govt. School Employees (Teaching \& Non - Teaching) & $\mathbf{9 0}$ & $\mathbf{9 3 . 2 7}$ & $\mathbf{9 . 5 9}$ & $\mathbf{0 . 5 8}$ & Insignificant \\
\hline Missionary School Employees (Teaching \& Non - Teaching ) & $\mathbf{9 0}$ & $\mathbf{9 2 . 4 7}$ & $\mathbf{8 . 9 4}$ & & \\
\hline
\end{tabular}

Table-7 clearly point out the significance of difference between government school employees (teaching \& non - teaching) and missionary schools (teaching \& non - teaching) in terms of their degree of perceived reactions towards work motivation (Total Sample). It could be seen from the Table-7 that Govt. school employees had scored little higher degree of perceived reactions towards work motivation (Mean 93.27 with an SD 9.59) as compared with the missionary schools (Mean - 92.47 with an SD 8.94). Thus, the formulated hypothesis i.e. the employee (teaching \& non - teaching) of government school will not differ on work motivation from the total employee (teaching \& non - teaching) working in missionary schools in the times of COVID-19 pandemic, stands accepted. The present results pertaining to the employees of government and missionary schools located in the Bihar State especially from where the present piece of research endeavor has been carried out during COVID - 19 pandemic seem to be logical in the sense that during COVID - 19 not only employees working in Government sector but all the employees were found to be afraid but instead of this they proved themselves to be active to work from home by maintaining social and physical distancing as guided by the World Health Organization during the COVID-19 pandemic.

\section{CONCLUSION}

On the basis of the obtained results and its interpretations discussed above the following conclusions are drawn:

1. Significance of difference between government and missionary school teachers in terms of their degree of work motivation during COVID-19 pandemic has not been found in North Bihar from where the present research work has been completed.

2. Significance of difference has been found between teaching and non - teaching employees working in government schools in terms of their degree of work motivation during COVID-19 outbreaks.

3. Significance of difference has also been found between the groups of teaching and non teaching employees working in missionary 
schools in terms of their degree of work motivation during COVID -19 pandemic.

4. It is very interesting to note that significance of difference has not been found between employees working in missionary and government schools in terms of their degree of perceived reactions on work motivation during COVID-19.

5. Government School teachers scored little higher on work motivation questionnaire than missionary school teachers during the COVID-19 outbreaks.

6. Government school teaching employees have been found more prone to work motivation than their non - teaching employees working in the same institutions.

7. Significance of difference between teaching and non - teaching employees working in missionary schools has also been found in terms of their degree of work motivation during pandemic.

8. Missionary school teachers have also been found more prone to work motivation than their non - teaching employees during the COVID-19 outbreaks.

9. Finally, observations have revealed the fact that both the group of employees working in government and missionary schools were found more or less afraid during the pandemic but they all had shown positive reactions to work motivation, hence, significant difference has not been found in total sample. Over all work environment of both the schools have been found positive during COVID-19 outbreaks.

\section{REFERENCES}

1. Pinder, C. C. (2008). Work motivation in organizational behavior (2nd edition). New York: Psychology Press.

2. Deckers, L. (2010). Motivation; Biological, Psychological and Environmental. (3rd ed., pp. 23). Boston, MA: Pearson.

3. Inceoglu, I., Segers, J., \& Bartram, D (2012). Agerelated differences in work motivationJournal of Occupational and Organizational Psychology, 85(2), 300-329.

4. Stajkovic, A. D., Latham, G. P., Sergent, K., \& Peterson, S. J. (2019). Prime and performance: Can a CEO motivate employees without their awareness?. Journal of Business and Psychology, 34(6), 791-802.
5. Mitchell, T. R., \& Daniels, D. (2003). Motivation. Handbook of Psychology, 12. Industrial Organizational Psychology, ed. Borman, W. C., Ilgen, D. R., \& Klimoski, R. J. pp. 225-54. New York: Wiley.

6. Klonoski, R. (2011). Work motivation, culture, and economic development: Is work motivation shaped by its socio-economic context? International Journal of Management \& Information Systems, 15(4):91-97.

7. Stoner-Weiss, K. (2002). Local heroes: The political economy of Russian regional governance. Princeton University Press.

8. Shafique, m. and Hussain, Akbar (2005). Work Motivation in Relation to Job Performance among Public and Private Sector Employee (Supervisors). Synthesis, Vol. 3, 1.

9. Robbins, S. p. (2003). Organizational Behavior, Prentice Hall of India: $7^{\text {th }}$ ed., New Delhi.

10. Ahmad, A. (2020). "The Definition of Work Motivation" https://bizfluent.com/facts-6951422definition-work-motivation.html

11. Kameri, R. H. (2004). Employee Motivation as it relates to Effectiveness, Efficiency, Productivity and Performance. Allied Academics International Conference, Proceedings of Academy of Legal, Ethical and Regulatory Issues, 8(2), Maui., 139.

12. Lee-Ross, D. (2002). An Exploratory Study of Work Motivation among Private and Public sector Hospitals Chefs in Australia. Journal of Management Development, 21(8):576-588.

13. Mishra, M. N. (2006). Organizational Behavior. Vikas Publishing House: New Delhi.

14. Patterson, M., Warr, P., \& West, M. (2004). Organizational Climate and Company Productivity: The Role of Employee Effect Employee Level. Journal of Occupational and Organizational Psychology. 77(2):193-216.

15. Pestonjee, D. M., \& Basu, G. (1972). Study of Job Motivation of Indian Executives. Indian Journal of Industrial Relations. July. 22.

16. Rollag, K. (2004). The Impact of Relative Tenure on Newcomer Socialization Dynamics. Journal of Organizational Behavior, 25(7):853-872.

17. Saiyadain, M. S., \& Monappa, A. (1977). Profile of Indian Managers, New Delhi Vidya Vahini.

18. Smith, F. J. (1977). Work Attitudes as Predictors of Attendance on a Specific day. Journal of Applied Psychology. 62, 16-19.

19. Agrawal, K. G. (1988). Work Motivation Questionnaire (WMQ), Manual, National Psychological Corporation, Agra. India. 